\title{
Photodynamic therapy of laryngeal cancers
}

\author{
Merrill Biel \\ From 2nd Scientific Meeting of the Head and Neck Optical Diagnostics Society \\ San Francisco, CA, USA. 23-24 January 2010
}

Carcinoma of the larynx accounts for 25-30 percent of all carcinomas of the head and neck. Early carcinomas of the larynx (Tis or T1) and severe dysplasia are presently treated with either radiation therapy or surgery alone. Radiation therapy, however, has significant disadvantages including mucositis during and for potential prolonged periods after therapy, permanently altered voice quality, dysphagia, chondroradionecrosis of the larynx and trachea, and the extensive length of therapy (6-7 weeks). Surgical therapy for early carcinomas of the larynx includes performing a partial cordectomy or hemilaryngectomy. Although cure rates are high, surgical removal of portions of the vocal cord or hemilarynx results in significant alteration of the quality of voice.

Photodynamic therapy has been demonstrated to be effective in the treatment of early carcinomas of the larynx, Tis and T1, with cure rates of $90 \%$ with followup to 236 months. The advantage of PDT therapy for early carcinomas of the larynx is the ability to preserve normal endolaryngeal tissue while effectively treating the carcinomas. This results in improved laryngeal function and voice quality. Furthermore, PDT requires a short duration of therapy as compared to radiation therapy, is repeatable and carries less risk than surgical therapy and is performed as an outpatient noninvasive treatment. Importantly, the use of PDT does not preclude the use of radiotherapy or surgery in the future for new primary or recurrent disease.

Published: 29 October 2010

doi:10.1186/1758-3284-2-S1-025

Cite this article as: Biel: Photodynamic therapy of laryngeal cancers. Head \& Neck Oncology 2010 2(Suppl 1):025.

Virginia Piper Cancer Institute, Minneapolis, USA

Submit your next manuscript to BioMed Central and take full advantage of:

- Convenient online submission

- Thorough peer review

- No space constraints or color figure charges

- Immediate publication on acceptance

- Inclusion in PubMed, CAS, Scopus and Google Scholar

- Research which is freely available for redistribution

Submit your manuscript at www.biomedcentral.com/submit
C Biomed Central 